\title{
Vitamin D-fortified foods improve wintertime vitamin D status in women of Danish and Pakistani origin living in Denmark: a randomized controlled trial
}

Grønborg, Ida Marie; Tetens, Inge; Christensen, Tue; Andersen, Elisabeth Wreford; Jakobsen, Jette; Kiely, Mairead; Cashman, Kevin D.; Andersen, Rikke

\author{
Published in: \\ European Journal of Nutrition
}

Link to article, DOI:

$10.1007 / \mathrm{s} 00394-019-01941-6$

Publication date:

2020

Document Version

Peer reviewed version

Link back to DTU Orbit

Citation (APA):

Grønborg, I. M., Tetens, I., Christensen, T., Andersen, E. W., Jakobsen, J., Kiely, M., Cashman, K. D., \& Andersen, R. (2020). Vitamin D-fortified foods improve wintertime vitamin D status in women of Danish and Pakistani origin living in Denmark: a randomized controlled trial. European Journal of Nutrition, 59, 741-753. https://doi.org/10.1007/s00394-019-01941-6

\section{General rights}

Copyright and moral rights for the publications made accessible in the public portal are retained by the authors and/or other copyright owners and it is a condition of accessing publications that users recognise and abide by the legal requirements associated with these rights.

- Users may download and print one copy of any publication from the public portal for the purpose of private study or research.

- You may not further distribute the material or use it for any profit-making activity or commercial gain

- You may freely distribute the URL identifying the publication in the public portal 


\section{Vitamin D fortified foods improve wintertime vitamin D status in women of Danish and Pakistani origin living in Denmark: A randomized}

controlled trial.

Ida M Grønborg ${ }^{1}$; Inge Tetens ${ }^{1,2}$; Tue Christensen ${ }^{1}$; Elisabeth W Andersen ${ }^{3,4}$; Jette Jakobsen ${ }^{1}$; Mairead Kiely ${ }^{5}$ K Kevin D Cashman ${ }^{5,6}$; Rikke Andersen ${ }^{1}$.

${ }^{l}$ National Food Institute, Technical University of Denmark, Lyngby, Denmark; ${ }^{2}$ Vitality - Centre for good older lives, Department of Nutrition, Exercise and Sports, University of Copenhagen; ${ }^{3}$ Danish Cancer Society, Section for Statistics and Pharmacoepidemiology, Copenhagen, Denmark; ${ }^{4}$ Institute of Applied Mathematics and Computer Science, Technical University of Denmark, Lyngby, Denmark; ${ }^{5}$ Cork Centre for Vitamin D and Nutrition Research, School of Food and Nutritional Sciences and ${ }^{6}$ Department of Medicine, University College Cork, Cork, Ireland.

Corresponding author: Ida M Grønborg, Division of Nutrition, National Food Institute, Technical University of Denmark, Lyngby, Denmark. Phone: +4520997801. E-mail: idamag@food.dtu.dk. Orcid ID: 0000-0001-7316-1073.

Running title: Food-based randomized controlled trial with vitamin D fortified foods

\section{Registered at ClinicalTrials.gov with identifier: NCT02631629.}

Financial support: This research was undertaken by the National Food Institute, Technical University of Denmark (DTU) and the study is a part of the European collaborative project "Food-based solutions for eradication of vitamin D deficiency and health promotion throughout the life cycle - ODIN", which was funded by the European Commission (FP7/2007-2013) under grant agreement no. 613977 (ODIN) and by the National Food Institute, Technical University of Denmark. The cheese and yoghurt products were produced and provided free of charge by FrieslandCampina. The eggs were produced and provided free of cost by Hedegaard Agro, including chicken feed produced by Dava Foods, the crisp bread was produced by Smørum konditori (confectionary) with ingredients provided free of cost by Lantmännen cerialia and vitamin $\mathrm{D}_{3}$ supplied by DSM Nutritional Products. 


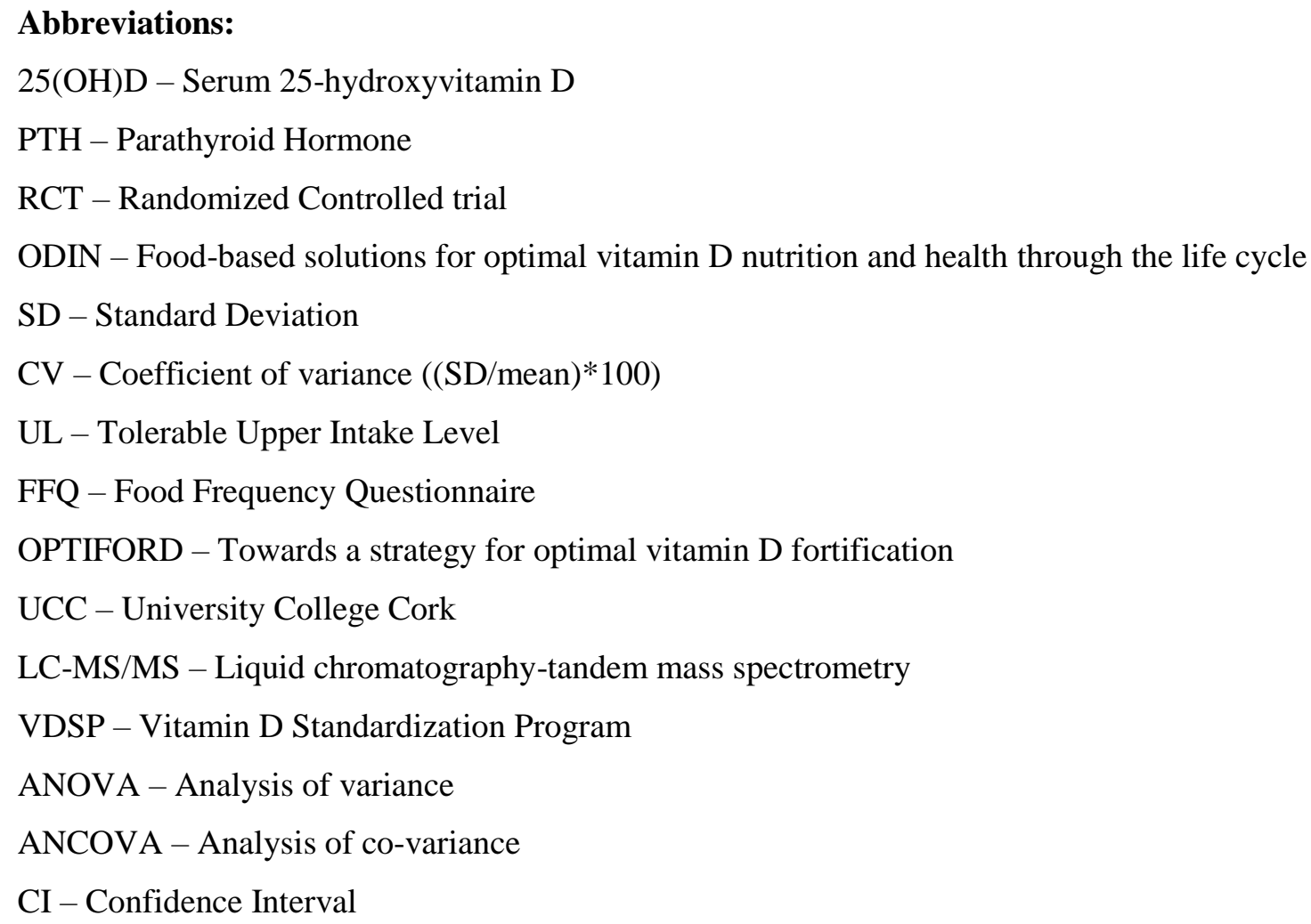




\section{ABSTRACT}

1 Purpose: Low vitamin D status is prevalent worldwide. We aim to investigate the effect of vitamin D 2 fortification on serum 25-hydroxyvitamin D (25(OH)D) concentration in women of Danish and Pakistani 3 origin at risk of vitamin D deficiency.

4 Methods: A 12-week randomized, double-blinded, placebo-controlled intervention trial during winter time, 5 designed to provide $20 \mu \mathrm{g}$ vitamin $\mathrm{D}_{3}$ /day through fortified yoghurt, cheese, eggs and crisp bread and assess 6 the change in serum 25(OH)D. Participants were 143 women of Danish and Pakistani origin, living in 7 Denmark, randomized into four groups, stratified by ethnicity.

8 Results: Mean (SD) baseline 25(OH)D concentrations among women of Danish and Pakistani origin were $949.6(18)$ and $46.9(22) \mathrm{nmol} / \mathrm{L}$, respectively $(P=0.4)$. While $9 \%$ of Danish women had $25(\mathrm{OH}) \mathrm{D}<30$ $10 \mathrm{nmol} / \mathrm{L}$, the prevalence among women of Pakistani origin was $24 \%$. Median (IQR) vitamin D intake among 11 Danish and Pakistani women at endpoint was $32.0(27.0,34.4) \mu \mathrm{g} / \mathrm{d}$ and $24.2(19.2,30.8) \mu \mathrm{g} / \mathrm{d}$, respectively. 12 Endpoint serum 25(OH)D increased in fortified groups to 77.8 (14) nmol/L among Danish women and 54.7 13 (18) nmol/L among women of Pakistani origin $(P<0.01)$. At endpoint, $0 \%$ in the Danish fortified group and $143 \%$ in the Pakistani fortified group had $25(\mathrm{OH}) \mathrm{D}<30 \mathrm{nmol} / \mathrm{L}$, compared with $23 \%$ and $34 \%$ in their 15 respective control groups.

Conclusions: Vitamin D fortification of four different foods for 12-weeks during winter was effective in increasing serum $25(\mathrm{OH}) \mathrm{D}$ and reducing the prevalence of very low vitamin D status among women of Danish and Pakistani origin.

19 Keywords: Vitamin D; Food-based RCT; ODIN; women of Pakistani origin; women of Danish origin; fortified foods. 
Very low and low vitamin D status (reflected by serum 25-hydroxyvitamin D [25(OH)D] concentrations < 30 and $<50 \mathrm{nmol} / \mathrm{L}$, respectively $[1,2])$ are prevalent amongst the general population in countries of northern latitudes [3], as well as being a more worldwide concern [4]. Notably, many immigrants (first generation immigrants and descendants) living in Denmark, and other Nordic countries, are at a higher risk of vitamin D deficiency compared to the native residents [3, 5-8]. Low vitamin D status has been linked with risk of various chronic diseases, and in particular, with adverse bone health outcomes [1, 2, 9-11].

Denmark, located at $55^{\circ}$ North, experiences a five-month long 'vitamin D winter', during which there is increased emphasis on dietary supply of vitamin D [12]. However, food sources of vitamin D are sparse (fish, meat, eggs, cheese) and their consumption patterns irregular [13]. Data from the most recent Danish National Survey of Dietary Habits and Physical Activity (DANSDA 2011-13) shows that median intakes of vitamin D are 3-4 $\mu$ g/day (without supplement contribution) [13], considerably lower than the Average Requirement of $7.5 \mu \mathrm{g} /$ day for the Nordic region [10]. In Denmark, while vitamin D supplement use is only recommended for populations at risk of deficiency; infants, pregnant women, elderly and individuals with dark skin [14], the proportion in the general population taking a vitamin D supplement is relatively high, e.g., $50-60 \%$ of the adult females $[15,16]$. However, while vitamin D supplementation is an effective approach for increasing vitamin D status in those individuals who consume them regularly, it has limitations as a strategy at a population level due to a high proportion of non-users as well as concerns about potential risk of excessive intake amongst high users [17].

Food-based strategies aiming at improving vitamin D intake and status across the population, such as vitamin D food fortification, have been highlighted as being of high potential as a public health measure in Europe [17-19]. Finland have been fortifying all fluid dairy products and margarine for more than 10 years and consequently experienced increases of the Finnish population vitamin D status [20]. In countries such as USA, Canada, food fortification with vitamin D have already been introduced using several different fortification vehicles such as milk, orange juice and margarine [21]. In India solutions such as fortification of 
commonly consumed stable foods are currently being investigated [22]. Furthermore, while many of the environmental factors that contribute to the elevated risk of vitamin D deficiency in populations, such as latitude, skin color, and cultural clothing practices are not modifiable, in contrast, dietary supply of vitamin D is an important modifiable factor, again emphasizing the need for food-based strategies to offset low intakes [23].

Vitamin D fortification of food has not yet been widely implemented and accepted in Denmark, despite voluntary fortification of certain foods being permissible for over a decade [19, 24]. Low-dose fortification of several foods rather than higher dose fortification in few foods has been proposed as an effective and safe strategy on the population level $[18,25]$. Yet, randomized controlled trial (RCT) data on the effectiveness and safety of this approach, especially in at-risk population subgroups, is lacking despite the importance of such data in informing food fortification policy. Thus, we aimed to investigate the effect of low-dose, vitamin $\mathrm{D}_{3}$ fortification of a number of commonly consumed foods (yoghurt, cheese, eggs and crisp bread) on vitamin D status in a population of adult women of Danish and Pakistani origin at increased risk of vitamin D deficiency, using a 12-week, winter-based RCT. 


\section{SUBJECTS AND METHODS}

Study design

The ODIN-FOOD study was part of the European Commission-funded large scale collaborative ODIN (Food-based solutions for optimal vitamin D nutrition and health through the life cycle) Project. The ODINFOOD study was a three-month randomized double-blinded, placebo-controlled, intervention trial carried out during the winter months (January-March) of 2016, and enrolled a total of 143 women of Danish and Pakistani origin, aged between 18 and 50 years. Immigrant women in Denmark are considered an at risk group for vitamin D deficiency $[5,7]$. The risk extends to the ethnic Danish female population in a modern work-life setting with a sedentary lifestyle, low UVB exposure and a low habitual vitamin D intake, particularly if they avoid or limit fish intake $[13,26]$. The trial was performed during the winter months to minimize interference from UVB-induced cutaneous synthesis of vitamin $\mathrm{D}_{3}$. Participants were randomized into four groups, stratified for ethnicity (two groups with women of Danish origin and two groups with women of Pakistani origin). The randomization sequence was generated by a researcher not involved in the project using block randomization with a block size of four within each ethnic group (Fig. 1). The subjects were given four different fortified foods aiming to contribute an additional $20 \mu \mathrm{g} /$ day of vitamin $\mathrm{D}_{3}$ or equivalent non-fortified foods (placebo). Participants were seen before the start of intervention and at the end of 3-month intervention, and at both visits non-fasting blood were drawn, anthropometrics, dietary vitamin D intake and muscle strength was measured. The main endpoint was the change in serum 25(OH)D concentration. Secondary endpoints included anthropometric measures and dietary intake of vitamin D.

The intervention was double-blinded, and the study foods were color and letter coded. The blinding was managed by a researcher not involved in the project. Both the participants and the researchers working within the project, during the intervention and subsequent analyses, were all blinded until the statistical analyses were completed. 
Sample size of 143 women of two ethnicities was based on $90 \%$ power (alpha $=5 \%$ ) to detect a change in serum $25(\mathrm{OH}) \mathrm{D}$ concentration of $20 \mathrm{nmol} / \mathrm{L}$ in the treatment groups with a standard deviation (SD) of 23 $\mathrm{nmol} / \mathrm{L}$, and included a drop-out rate of $20 \%$.

\section{Subjects}

We recruited women of Pakistani origin (first generation immigrants or descendants) and women of Danish origin from the Copenhagen area, city and suburbs (Denmark, $\left.55^{\circ} \mathrm{N}\right)$. The recruitment was done by e-mail, advertising, networking and interactions with local community groups, media, and social and cultural initiatives in the Copenhagen area, as well as visiting local shops, libraries, mosques and women's societies. Eligible women were invited to information meetings in which the study procedures were explained by a researcher from the project group. Written informed consent was obtained from all participants on enrolment. Inclusion criteria were a low consumption of fish and fish products (less than weekly), a low frequency of use of vitamin D-containing supplements (less than weekly), no use of tanning facilities, no planned sun-holiday (to a location more southerly than $47^{\circ} \mathrm{N}$ ) between October 2015 and May 2016. There was no upper limit on the vitamin D dose of the supplements as long as participants discontinued them during the study period. Exclusion criteria were pregnancy and breastfeeding, menopause, non-Danish speakers, serious diseases (cancer, server liver or kidney insufficiencies, sarcoidosis and other granulomatous diseases) and medicines affecting vitamin D metabolism (steroids, antiepileptic, thyroid hormones, bisphosphonates, estrogen).

\section{Fortification vehicles}

The intervention foods of choice were low-fat Milner cheese (gouda) and yoghurt (plain) produced and provided free of cost by FrieslandCampina in the Netherlands, eggs (Livskraft) produced and provided free of cost by Hedegaard in Denmark, and whole grain crisp bread produced by Smørum Konditori (confectionary) using ingredients provided free of cost by Lantmännen Cerealia, Denmark, the vitamin $\mathrm{D}_{3}$ for the crisp bread was supplied by DSM nutritional products, Switzerland. The study foods were chosen because they are commonly consumed by both ethnic groups. Dietary calculations and pilot taste tests were 
carried out to ensure the acceptance of the products. The taste tests were performed among 12 women of Danish and Pakistani origin. The majority of the foods were low in fat and they are considered suitable substitutions for the participants' habitual intake of these food products (Table 1). The participants were given either placebo foods or vitamin D-fortified foods (aimed at providing approximately $20 \mu \mathrm{g} / \mathrm{day}$ of additional vitamin $\mathrm{D}_{3}$ ) [19] at no cost for the participants.

A daily dose of $20 \mu \mathrm{g}$, together with the contribution from habitual intake ( 3-4 $\mu \mathrm{g} / \mathrm{d}$ [6]), would be expected to maintain winter serum $25(\mathrm{OH}) \mathrm{D}$ concentration above of $30 \mathrm{nmol} / \mathrm{L}$ in the vast majority of individuals [27] and it allows for a large margin of safety in relation to the Tolerable Upper Intake Level (UL) of $100 \mu \mathrm{g} / \mathrm{day}$ $[19,28]$. The fortified and non-fortified foods have the same fat content and comparable content of nutrients, except for the vitamin D concentration (Table 1). The packaging of the food products was identical, except for color and letter coding added to distinguish the fortified from the placebo foods.

\section{Laboratory analysis of food samples}

The vitamin $\mathrm{D}_{3} / \mathrm{D}_{2}$ and 25-hydroxyvitamin $\mathrm{D}_{3} / \mathrm{D}_{2}$ content of food were analyzed at the National Food Institute at the Technical University of Denmark using modifications of a sensitive liquid chromatographytandem mass spectrometry (LC-MS/MS), as described elsewhere [29]. The analysis was performed in a laboratory accredited according to ISO17025, and has a limit of quantification at $0.01 \mu \mathrm{g} / 100 \mathrm{~g}$, and a precision $<10 \%(\mathrm{CV})$. For crisp bread and eggs, eight and six batches, respectively, were produced and all were analyzed. Only one batch was produced for yoghurt and cheese and for this the stability was controlled. Analysis confirmed there was no decrease of vitamin D during the 12 weeks of intervention. Total vitamin D activity of each food was calculated as the vitamin $\mathrm{D}_{3}$ content of the food plus the 25-hydroxyvitamin $\mathrm{D}_{3}$ content $x$ 2.5. The conversion factor of 2.5 was used as a conservative estimate based on factor of 5 as currently used [30] and a factor of 1.5 recently obtained in an intervention study in Denmark [31].

\section{Intervention}

After the baseline visit, participants were each given food for two weeks (1 egg per day, $150 \mathrm{~g}$ (1 small pot) yoghurt, $60 \mathrm{~g}$ ( 2 slices) of low fat Gouda cheese and 1 crisp bread per day). The participants were allowed to 
freely plan how they distributed the provided foods over a week as long as they consumed the designated 7 eggs, 7 portions of yoghurt, 7 x $60 \mathrm{~g}$ cheese and 7 crisp breads per week. To maintain body weight, participants were advised to substitute some of their regularly consumed foods with the study foods. Fresh foods were distributed every two weeks. Adherence/compliance was monitored on a weekly basis by a userfriendly printed questionnaire in which the participant would mark each food item on a picture once consumed. Adherence was estimated individually by dividing the individual amount of food received by selfreported adherence, expressed as a percentage. Due to packaging, an individual would sometimes receive more than they needed for that period, and were asked not to consume the surplus after fulfilling their weekly amount, however, if they did consume the extra foods, this was accounted for. Thus, individual adherence could in some cases be $>100 \%$.

\section{Measurements}

Participants were examined twice at the National Food Institute at the Technical University of Denmark, including a baseline visit in January and an endpoint visit in April 2016. At each visit, a $40 \mathrm{~mL}$ non-fasting blood sample was obtained from each participant by an experienced phlebotomist or nurse.

Anthropometric measures were completed with participants wearing thin/light clothing, no shoes and after emptying their bladder. The measures were height (wall mounted stadiometer, seca, Hamburg, Germany) and weight, waist-hip circumference (standard tape measure) and body composition (Tanita BC 418 MA, Tokyo, Japan).

At baseline, participants completed two questionnaires, a general background questionnaire, assessing the health, lifestyle and sun habits, and other factors affecting the vitamin D status and a semi-quantitative Food Frequency Questionnaire (FFQ) estimating the average intake of vitamin D and calcium. The FFQ was a retrospective questionnaire asking about the participants' habitual dietary intake of vitamin D-rich foods over the 3 preceding months. The FFQ used in the ODIN-FOOD study was developed from existing questionnaires used in previous RCT's (OPTIFORD and VitmaD) at the National Food Institute [5, 24]. 
All questionnaires were self-administered, however to ensure that all participants completed the questionnaire and to avoid misunderstandings, cultural as well as language-related, we set up a questionnaire room, where all participants were introduced to the questionnaires and offered help when needed. The questionnaires contained ethnic-specific questions regarding foods that contribute vitamin D and calcium. All FFQ's were administered during the participant's first visit in January 2016. The questionnaire contained the 8 food groups (Fish, meat, milk and milk products, egg, cheese, bread, fats and pulses) contributing to the majority of dietary vitamin D (98\%) and calcium (71\%) [13]. Further questions were asked to estimate intake of vitamin D-containing supplements prior to the study start. The questionnaire took between 30 and 50 minutes to complete and all participants completed the questionnaire.

Estimates of vitamin D intake were made from the data obtained from the FFQ matched to specific foods and recipes made from the Danish food composition database (version 7) using the individually reported portion sizes [32]. The total vitamin D intake for each participant prior to the study start was estimated as the sum of dietary vitamin D and contribution from personal supplements, if consumed.

\section{Laboratory analysis of blood samples}

Serum concentrations of total $25(\mathrm{OH}) \mathrm{D}$ (i.e., $25(\mathrm{OH}) \mathrm{D}_{2}$ plus $25(\mathrm{OH}) \mathrm{D}_{3}$ ) of all serum samples (baseline and endpoint visits) were measured at the Cork Centre for Vitamin D and Nutrition Research, University College Cork (UCC), using the ODIN core LC-MS/MS analytical platform for serum 25(OH)D, described in detail elsewhere [33]. The intra-assay CV of the method was $<5 \%$ for all $25(\mathrm{OH}) \mathrm{D}$ metabolites, whilst the interassay CV was $<6 \%$. The LC-MS/MS method at UCC is certified by the Center for Disease Control and Prevention's Vitamin D Standardization Certification Program.

The biochemical analyses of serum calcium and PTH were performed at the University Hospital Aarhus. Total serum calcium had an analysis precision of $\pm 0.032 \mathrm{mmol} / \mathrm{L}$ (standard deviation $[\mathrm{SD}]$ ) at a concentration of $2.161 \mathrm{mmol} / \mathrm{L}$ and $\pm 0.047 \mathrm{mmol} / \mathrm{L}(\mathrm{SD})$ at a concentration of $3.134 \mathrm{mmol} / \mathrm{l}$. Serum PTH had a precision of $\pm 0.2 \mathrm{pmol} / \mathrm{L}(\mathrm{SD})$ at a concentration of $2 \mathrm{pmol} / \mathrm{L}$ and $\pm 1.0 \mathrm{pmol} / \mathrm{L}(\mathrm{SD})$ at a concentration of $10 \mathrm{pmol} / \mathrm{l}$. 
Results are shown as means and SDs unless otherwise specified. Descriptive statistics were generated for the two ethnic groups at baseline, and the groups were compared using a two-sample $t$ test when the data could be assumed to be normal; otherwise using a non-parametric Kruskal Wallis test. Categorical variables were compared using a Pearson's chi-square test.

Comparison of the daily vitamin D intake, serum 25(OH)D and serum PTH at baseline and endpoint across the intervention groups were done by simple one way ANOVA and if significant differences were observed a Tukey HSD test were performed in order to assess differences between groups. Analysis of covariance (ANCOVA) was used to analyze the effect of the intervention on the outcome variable change in vitamin $D$ status (endpoint - baseline 25(OH)D). Two models were run - a minimal adequate model (Model 1) and a maximal model (Model 2), which controlled for specific covariates that may influence the outcome. Model 1 included baseline $25(\mathrm{OH}) \mathrm{D}$ as a covariate and the factors intervention group, ethnicity and their interaction allowing the effect of intervention to differ between the two groups of women. The interaction was tested for statistical significance to see whether the model could be simplified. In Model 2, the covariates Age and BMI at baseline were added to Model 1 construct as they are likely to have a strong association with the outcome (serum 25(OH)D) [34]. The variables were chosen based on factors known to affect the change in vitamin $\mathrm{D}$ status following fortification and variables associated with missing outcomes as well as the variables that were significantly different between the two ethnic groups at baseline.

To check the model assumptions the standardized residuals of the final models were assessed for normality, variance homogeneity and linearity. 


\section{RESULTS}

204 A total of 143 women of Danish and Pakistani origin were randomly allocated to either vitamin D-fortified 205 foods or placebo (similar non-fortified foods), forming the four study groups. The completion rate of the study was $89 \%$ with the number of drop-outs at 16 in total for reasons as described within the Consort flow diagram in Fig. 1. Drop-outs were equally distributed across the two ethnic groups $(P=0.67)$. In total, six participants who finished the intervention were excluded from the analyses due to unplanned travels to countries more southerly than $47^{\circ} \mathrm{N}$ during the study period and one was excluded as an outlier due to a baseline serum 25(OH)D concentration $>125 \mathrm{nmol} / \mathrm{L}$, which the Institute of Medicine (IOM) suggest is potentially of concern, if sustained [1].

Adherence to consumption of the study foods was $92 \%$ among participants of Danish origin and $73 \%$ among participants of Pakistani origin $(P<0.05)$. The study foods and the habitual dietary intake contributed to a median $\left(25^{\text {th }}, 75^{\text {th }}\right.$ percentiles $)$ daily intake of vitamin $D$ of $32.0(27.0,34.4) \mu \mathrm{g} / \mathrm{day}$ in the participants of Danish origin randomized to the fortified food study group, and $24.2(19.2,30.8) \mu \mathrm{g} / \mathrm{day}$ in the participants of Pakistani origin randomized to the fortified food study group (Table 3). The chemical analysis of the crisp bread showed a slightly higher concentration of vitamin D than expected due to a calculation error in the production of the flour mix, whereas the eggs contained less vitamin D than expected due to lower vitamin D $\left(\mathrm{D}_{3}\right.$ and $\left.25(\mathrm{OH}) \mathrm{D}_{3}\right)$ doses in the chicken feed than expected, and this led to a slightly higher total daily contribution of vitamin D from fortified foods (Table 1). The margin of safety was still sufficient (UL:100 $\mu \mathrm{g} /$ day) [19].

\section{Baseline characteristics of the participants}

There were no differences in baseline characteristics between the groups receiving vitamin D-fortified foods or placebo foods within either ethnicity (data not shown); however, there were significant differences in some baseline anthropometric characteristics between the two ethnic groups (Table 2). Women of Pakistani origin had a significantly higher mean BMI and fat percentage compared to the women of Danish origin $(P=$ 0.004 and $P<0.001$, respectively). The intake of supplements containing only vitamin D was significantly 
higher among the women of Pakistani origin compared to the women of Danish origin $(P=0.001)$. More than $60 \%$ of the women of Pakistani origin reported taking a supplement with vitamin D before study start. The proportion of the participants using multivitamins was statistically similar in the two ethnic groups $(P>$ 0.30) (Table 2). No significant differences $(P>0.05)$ were found in mean age between the two ethnic groups (Table 2). The intake of vitamin D from dietary sources were significantly higher among the women of Danish origin $(P<0.05)$, however both groups had very low intake.

Mean $( \pm \mathrm{SD})$ serum $25(\mathrm{OH}) \mathrm{D}_{3}$ concentration at baseline was similar in women of Danish and Pakistani origin (49.6 $\pm 18 v .46 .9 \pm 22 \mathrm{nmol} / \mathrm{L}$, respectively; $P=0.80)$, shown in Table 2. At baseline, none of the participants, irrespective of ethnicity, had serum $25(\mathrm{OH}) \mathrm{D}<10 \mathrm{nmol} / \mathrm{L}$. The prevalence of $25(\mathrm{OH}) \mathrm{D}<30$ $\mathrm{nmol} / \mathrm{L}$ and $<50 \mathrm{nmol} / \mathrm{L}$ was 9 and $50 \%$ of the women of Danish origin and 24 and $32 \%$ of the women of Pakistani origin, respectively.

While serum $25(\mathrm{OH}) \mathrm{D}_{2}$ was significantly higher in the women of Danish origin compared to women of Pakistani origin (median $[\mathrm{IQR}] 2.0[1.3-2.4]$ v. $1.0[0.7-1.5] \mathrm{nmol} / \mathrm{L} ; P=0.0001)$, overall serum $25(\mathrm{OH}) \mathrm{D}_{2}$ only represented $4 \%$, on average, of serum total $25(\mathrm{OH}) \mathrm{D}$ in the entire group of women at baseline.

Baseline serum PTH was significantly higher among the women of Danish origin than of Pakistani origin $(P$ $<0.02$ ), but all group values were within the reference range for normal PTH (Table 2). While serum PTH was positively associated with serum $25(\mathrm{OH}) \mathrm{D}$ at baseline among the women of Pakistani origin $(P=0.02)$, there was no significant $(P>0.90)$ association between these two variables in women of Danish origin (data not shown).

\section{Effect of intervention}

The following analyses included 136 individuals following a complete case intention-to-treat approach. We saw no significant differences in drop-outs between study groups $(P=0.8)$. There were no significant changes in body weight (between baseline and endpoint) in either ethnic group ( $P=0.70$ and $P=0.66$ for Danish and Pakistani women, respectively) (data not shown). 
The total vitamin D intake from the fortified foods during the intervention was higher among the Danish women, compared to the women of Pakistani origin $(P=0.004)$, reflecting the lower adherence of the women of Pakistani origin. The mean (SD) endpoint serum 25(OH)D concentration among the women of Danish origin in the fortified food group was 77.8 (15) nmol/L, whereas among the women of Pakistani origin in the fortified food group, it was significantly $(P<0.01)$ lower at $54.7(18) \mathrm{nmol} / \mathrm{L}$ (Table 3$)$. The mean increase in serum $25(\mathrm{OH}) \mathrm{D}$ concentration from baseline to endpoint among the fortified food group was higher $(P<0.01)$ in the women of Danish origin $(\Delta 26.4(16) \mathrm{nmol} / \mathrm{L})$ compared to that in the women of Pakistani origin $(\Delta 10.5(18) \mathrm{nmol} / \mathrm{L})$. Serum 25(OH)D decreased by $2.8(9) \mathrm{nmol} / \mathrm{L}$ in the Danish placebo group and by $11.2(12) \mathrm{nmol} / \mathrm{L}$ in the Pakistani placebo group over the 12 weeks of winter $(P=0.02)$. While endpoint serum $25(\mathrm{OH}) \mathrm{D}_{3}$ concentration was unaltered $(P=0.09)$ or significantly decreased $(P<0.0001)$ in women of Danish and Pakistani origin in their respective placebo groups (mean $( \pm \mathrm{SD})$ change from pre- to post-intervention: $-2.8 \pm 9.0$ and $-11.4 \pm 12.5 \mathrm{nmol} / \mathrm{L}$, respectively), it significantly increased in both Danish and Pakistani women in the fortification groups $(+26.9 \pm 16.1 \mathrm{nmol} / \mathrm{L}, P<0.0001$ and $+10.2 \pm 18.0 \mathrm{nmol} / \mathrm{L}$, $P=0.004$, respectively). Compared to pre-intervention, mean endpoint serum $25(\mathrm{OH}) \mathrm{D}_{2}$ was unaltered in women of either Danish or Pakistani origin, irrespective of placebo or fortification groups $(P>0.11$ in all cases; data not shown).

Following the intervention, none of the women of Danish origin in the fortified group had a serum $25(\mathrm{OH}) \mathrm{D}$ concentration $<50 \mathrm{nmol} / \mathrm{L}$. Among the women of Pakistani origin, 3 and $41 \%$ of the fortified food group had an endpoint serum 25(OH)D concentration $<30$ and $<50 \mathrm{nmol} / \mathrm{L}$, respectively (Table 3). In contrast, vitamin D deficiency (serum $25(\mathrm{OHD}<30)$ was evident in about a quarter of the Danish and a third of the Pakistani women in the placebo groups at endpoint. Likewise, vitamin D insufficiency (serum 25(OHD $<50)$ was evident in about two-thirds and three-quarters of the Danish and Pakistani women in the placebo groups, respectively, at endpoint (Table 4).

There was no significant increase in PTH concentration of the placebo groups (Danish and Pakistani) following the intervention ( 0.21 and $P=0.85$, respectively, $t$ test $)$. Likewise, there was no significant 
decrease in PTH concentration of the fortified food groups (Danish and Pakistani) following the intervention $278 \quad(P=0.40$ and 0.58 , respectively, $t$ test $)$.

279 Analysis of covariance including factors influencing the change in serum 25(OH)D following the intervention

281 Based on the output of Model 1, compared to that of an equivalent woman in the non-fortified group, 12 282 weeks of intervention with vitamin D fortified foods (together with habitual diet, collectively supplying a 283 total of $30 \mu \mathrm{g}$ vitamin D/day), resulted in an improvement of endpoint serum 25(OH)D of $31.1 \mathrm{nmol} / \mathrm{L}$ (25.0; 284 37.2) and $20.3 \mathrm{nmol} / \mathrm{L}(14.3 ; 26.3)$ in the women of Danish and Pakistani origin, respectively (Table 5). The 285 intervention effect is significantly higher in the Danish group compared to the Pakistani group $(P=0.008)$.

286 In terms of other factors which affected the response of serum $25(\mathrm{OH}) \mathrm{D}$ to intervention, the ANCOVA 287 models showed that baseline 25(OH)D status and BMI had a negative effect on the change in serum $28825(\mathrm{OH}) \mathrm{D}$ following the intervention, however the effect of BMI was very small (Model 2). Model 2 was also run where body weight was substituted for BMI but this did not affect the findings majorly (e.g., for body 290 weight at baseline, Effect $=-0.18, \mathrm{P}$ value $=0.04)($ data not shown $)$. According to the model, participants 291 with e.g. a higher baseline serum 25(OH)D had an expected lower increase in serum 25(OH)D following the intervention (Table 5). 


\section{DISCUSSION}

The present study demonstrated that fortification of four different foods for 12 weeks during winter (January through to March) was effective in increasing serum 25(OH)D among Danish and Pakistani women and reduced the prevalence of low and very low vitamin D status during the winter months. The Danish fortified group increased significantly more than the fortified Pakistani group. To our knowledge few previous studies have assessed the effects of vitamin D food fortification with two different ethnic groups [36] and none in Denmark, the results of our study may be of importance for the planning of fortification policies in countries with multi-ethnic populations and no vitamin $\mathrm{D}$ fortification program.

The increase in serum $25(\mathrm{OH}) \mathrm{D}$ of the fortified participants was mainly dependent on baseline serum 25(OH)D and ethnicity in accordance with the linear models. However, we saw significant difference in the intake of vitamin D from the fortified foods provided in the study due to a lower adherence in the women of Pakistani origin compared to women of Danish origin. Generally, the results show a successful preventative effect of an intervention with vitamin D-fortified foods in a country without mandatory fortification in a population of women at risk of deficiency, as well as an important effect in terms of maintaining serum $25(\mathrm{OH}) \mathrm{D}>50 \mathrm{nmol} / \mathrm{L}$ (reflective of sufficiency) in all participants of Danish origin and in $60 \%$ of the participants of Pakistani origin.

These results are in line with the findings of an 11-year Finnish follow-up study which showed a positive effect of an implementation of a national voluntary vitamin D fortification policy. The study revealed an average increase in vitamin D status of $20 \mathrm{nmol} / \mathrm{L}(95 \% \mathrm{CI}: 19,21)$ among supplement non-users, although no records of ethnic background was obtained [20].

Several studies have investigated fortification of a single food, but only few have experience from low dose fortification of several foods $[17,24]$. We decided on a low-dose approach in which the daily dose of vitamin D was spread out into several (four) foods in order to ensure the effectiveness and safety in a population approach, based on previous experience [24, 25]. Our study participants were of Danish and Pakistani origin, therefore we made special considerations when choosing the fortification vehicles since acceptance of the foods in both groups was of high importance. As an example of our considerations we did not use milk as a 
fortification vehicle despite its use in previous Nordic studies [20,24, 25], since the prevalence of lactose intolerance among individuals of Pakistani origin is $>60 \%$ [37]. Instead we chose plain yoghurt. Yoghurt has lower concentrations of lactose, and more importantly it contains the enzyme B-galactosidase which, by intra-intestinal digestion, enables lactose intolerant people to absorb more lactose [38]. Yoghurt is thus better tolerated by lactose intolerant people, compared to milk. Additionally, it can be used in breakfast, snacks and sweet or savory cooking.

All the study foods were provided with no cost for the participants in portions that fit into a healthy diet. The foods were all low in fat and energy. We instructed the participants to substitute their normal diet with food from the study, so that they would remain approximately isocaloric throughout the study. This was successful and we saw no changes in the body composition (BMI) of the participants following the intervention.

The effect of intervention with fortified foods on vitamin D status was significantly different in the two ethnic groups. This ethnic difference may in part be explained by the differences in adherence with the study foods as adherence while high (73\%) was significantly lower in the Pakistani women. Assessing the distribution of baseline serum $25(\mathrm{OH}) \mathrm{D}$ it was evident that despite a similar mean vitamin $\mathrm{D}$ status, the IQR revealed a much longer tail among the women of Pakistani origin which was evident as per the higher percentage $<30 \mathrm{nmol} / \mathrm{L}$. In the statistical models ethnicity was significant and there could be some ethnicspecific differences in the serum $25(\mathrm{OH}) \mathrm{D}$ response that stem from genetic variation of vitamin $\mathrm{D}$ modulating genes. Analyses of Single Nucleotide Polymorphism (SNP) data collected in this study, but not yet studied, may explain parts of the found ethnic specific intervention effect.

341 We found that the baseline serum 25(OH)D among the women of Pakistani origin was higher than expected 342 (mean $\approx 50 \mathrm{nmol} / \mathrm{L})$, when compared with data from a previous Danish study which included only 343 participants of Pakistani origin living in Denmark. In that study, conducted in 2002, a low vitamin D status was reported for both girls and women of Pakistani origin (median serum 25(OH)D was 10.9 and 12.0 
nmol/L, respectively) [5]. It should be noted, however, that the earlier study by Andersen et al. [5] was

346 performed prior to the initiation of the Vitamin D Standardization Program (VDSP) and this may affect the comparability of serum $25(\mathrm{OH}) \mathrm{D}$ data. More importantly, several factors may have affected the change in vitamin D status over the course of the last $15+$ years. For example, it may partly be a result of the strong focus on vitamin D in the general public as well as public health actions initiated by the Danish health authorities between 2005 and 2010, targeting the general population, ethnic minorities as well as health professionals $[39,40]$.

An additional result of the mentioned public health actions may be an increased intake of dietary supplements containing vitamin D. In our study we saw a relatively high self-reported intake of vitamin D from supplements, importantly, participants taking supplements prior to the study start were asked to stop their supplement routine for the duration of the intervention study. The prior intake of vitamin D-containing supplements was adjusted for by ensuring that baseline serum $25(\mathrm{OH}) \mathrm{D}$ concentration was an input in all of the linear models. We did not intend to perform a screening serum $25(\mathrm{OH}) \mathrm{D}$ test prior to study start due to ethical reasons as well as the time constraint present in this vitamin D RCT's due to the relatively short study period of a winter only study.

\section{Strengths and limitations}

This study was a real-life based design in which the participants would incorporate the study foods by for this study population. are therefore highly needed in order to give suitable health advice and ensure equality in health of all citizens 
in Denmark. The trial was carried out in winter time when there is no cutaneous production of vitamin D,

373 this lowers the risk of vitamin D contribution from UV sources which would confound the intake-status 374 relationship.

375 The intake of dietary vitamin D was very low, compared to the Danish National Survey of Dietary Habits and Physical Activity (DANSDA 2011-13) [13], however, the participants were recruited based on their low intake of fish, so this was not surprising. The dietary calcium intake recorded in the FFQ was also low, especially considering the habitual dietary intake of calcium in Denmark which is on average approximately $1000 \mathrm{mg} /$ day, among women [13]. The calcium intake data suggest that the study participants are in the lower 25th percentile of the distribution intake range of age matched women in the general Danish population [13]. One methodological explanation may be that the questionnaire, which was focused on dietary vitamin $\mathrm{D}$, was not designed to capture more than about $70 \%$ of dietary calcium. The chemical analysis of the crisp bread showed a slightly higher concentration than expected due to a calculation error in the production of the flour mix, whereas the eggs contained less vitamin D than expected due to lower vitamin $\mathrm{D}\left(\mathrm{D}_{3}\right.$ and $\left.25(\mathrm{OH}) \mathrm{D}_{3}\right)$ doses in the chicken feed than expected, and this affected the total daily dose from fortified foods of approximately $30 \mu \mathrm{g} /$ day (Table 1 ).

Results of the present study may be applicable for designing fortification policies prior to implementing them in modern multiethnic population groups in Denmark. Though the road to implementation of a national fortification program may be country specific, the overall goal is the same, improving vitamin $\mathrm{D}$ status of the population, with a minimal risk of toxicity [41]. Data from countries such as Finland, having already implemented widespread systematic vitamin D fortification, show that fortification is effective in terms of increasing vitamin D status on a population level [41]. Future studies may go further into the topic of vitamin with the VDSP when analyzing the serum $25(\mathrm{OH}) \mathrm{D}$ concentration. 
397 Vitamin D fortification of $30 \mu \mathrm{g} /$ day, provided in four different foods, for 12 weeks during winter was 398 effective in increasing vitamin D status and preventing vitamin D deficiency in women of Danish and 399 Pakistani origin living in Denmark. Women of Pakistani origin had a lower response to the intervention that 400 did women of Danish origin. Adherence was lower among the women of Pakistani origin compared to the 401 women of Danish origin. 


\section{Acknowledgements}

403 We thank the following individuals for their help and assistance with this trial: Majken Ege, Karin Hess Ygil, 404 Dorte L Korsbech, Erika Baig for assisting with the measurements, dietary intake calculations and FFQ 405 work, Bashy Quraishy, Raza Mustafa, Saima Raza, Shahnaz Qureshi and Shais Anais for introducing us to 406 the Pakistani societies in Copenhagen, Denmark. We would also like to thank Dr. George Hull and Ms. 407 Kirsten Dowling at University College Cork for their contribution to the analysis of serum 25(OH)D within 408 the ODIN project. We thank our industrial partners FrieslandCampina, Hedegaard, Lantmännen Cerealia and 409 DSM nutritional products for delivering the foods used in the trial.

410 Contributors: IMG and RA collected the data, TC managed intake data, JJ analyzed the vitamin D content 411 of the food, KC oversaw the analysis of serum $25(\mathrm{OH}) \mathrm{D}$, IMG undertook the statistical analyses and wrote 412 this paper. EWA assisted with the statistical analyses. RA, IT, KC and MK designed the study. All 413 contributed to the manuscript.

\section{Ethical standards:}

415 Written informed consent was obtained from all participants on enrolment. The study protocol was approved 416 by the local ethical committee (protocol no. H-15008276) and registered at ClinicalTrials.gov with identifier: 417 NCT02631629. The study was carried out in accordance with the Declaration of Helsinki.

\section{Conflicts of interest:}

419 None of the authors had conflicts of interest. The industry partners had no influence on the design of the 420 study, the interpretation of the results or the writing of this manuscript. 


\section{REFERENCES}

1. Ross AC, Taylor CL, Yaktine AL, Del Valle HB (2011) Calcium and Vitamin D. Institute of Medicine, the National Academic Press, Washington D.C.

2. EFSA Panel on Dietetic Products Nutrition and Allergies (NDA) (2016) Scientific Opinion on Dietary Reference Values for vitamin D. EFSA J 1-179. doi: 10.2903/j.efsa.2016.NNN

3. Cashman KD, Dowling KG, Skrabakova Z, et al (2016) Vitamin D deficiency in Europe: pandemic? Am J Clin Nutr 103:1033-1044. doi: 10.3945/ajcn.115.120873.

4. Holick M, Chen T (2008) Vitamin D deficiency: a worldwide problem with health consequences. Am J Clin Nutr 87:1080-1086.

5. Andersen R, Mølgaard C, Skovgaard LT, et al (2008) Pakistani immigrant children and adults in Denmark have severely low vitamin D status. Eur J Clin Nutr 62:625-634. doi: 10.1038/sj.ejen.1602753

6. Andersson $\AA$, Björk A, Kristiansson P, Johansson G (2013) Vitamin D intake and status in immigrant and native Swedish women: a study at a primary health care centre located at 60 oN in Sweden. Food Nutr Res 1:1-8.

7. Meyer HE, Falch JA, Søgaard AJ, Haug E (2004) Vitamin D deficiency and secondary hyperparathyroidism and the association with bone mineral density in persons with Pakistani and Norwegian background living in Oslo, Norway, The Oslo Health Study. Bone 412-417. doi: 10.1016/j.bone.2004.04.003

8. Cashman KD, Dowling KG, Škrabáková Z, et al (2015) Standardizing serum 25-hydroxyVitamin D data from four Nordic population samples using the Vitamin D Standardization Program protocols: Shedding new light on Vitamin D status in Nordic individuals. Scand J Clin Lab Invest 75:549-561. doi: 10.3109/00365513.2015.1057898

9. Holick MF (2006) Resurrection of vitamin D deficiency and rickets. J Clin Invest 116:2062-2072. doi: $10.1172 / \mathrm{JCI} 29449$

10. Nordic council of Ministers (2014) Nordic Nutrition Recommendations, 5th ed. København

11. SACN (Scientific Advisory Commitee on Nutrition) (2016) Vitamin D and Health. 116-130.

12. Brot C, Vestergaard P, Kolthoff N, et al (2001) Vitamin D status and its adequacy in healthy Danish perimenopausal women: relationships to dietary intake, sun exposure and serum parathyroid hormone. Br J Nutr 86:97-103. doi: 10.1079/BJN2001345

13. Pedersen AN, Christensen T, Matthiessen J, et al (2015) Danskernes kostvaner 2011-2013 [Danish Dietary survey]. Søborg

14. Danish National Health Authority (2010) Vitamin D: Prevention of deficiency.

15. Knudsen VK (2014) Danskernes forbrug af kosttilskud (The use of dietary supplements in Denmark). e-paper Natl. Food Institute, DTU

16. Tetens I, Biltoft-Jensen A, Spagner C, et al (2011) Intake of micronutrients among Danish adult users and non-users of dietary supplements. Food Nutr Res 55:1-8. doi: 10.3402/fnr.v55i0.7153

17. Cashman KD, Kiely M (2016) Tackling inadequate vitamin D intakes within the population: 
fortification of dairy products with vitamin D may not be enough. Endocrine 51:38-46. doi: 10.1007/s12020-015-0711-x

18. Kiely M, Black LJ (2012) Dietary strategies to maintain adequacy of circulating 25-hydroxyvitamin D concentrations. Scand J Clin Lab Invest Suppl 243:14-23. doi: 10.3109/00365513.2012.681893

19. Grønborg IM, Tetens I, Ege M, et al (2018) Modelling of adequate and safe vitamin D intake in Danish women using different fortification and supplementation scenarios to inform fortification policies. Eur J Nutr 1-6. doi: 10.1007/s00394-017-1586-9

20. Jääskeläinen T, Itkonen ST, Lundqvist A, et al (2017) The positive impact of general Vitamin D food fortification policy on Vitamin D status in a representative adult Finnish population: Evidence from an 11-y follow-up based on standardized 25-hydroxyVitamin D data. Am J Clin Nutr 105:1512-1520. doi: 10.3945/ajen.116.151415

21. Calvo MS, Whiting SJ, Barton CN (2004) Vitamin D fortification in the United States and Canada: current status and data needs 1 - 4 LAWFUL ADDITION OF VITAMIN D TO FOODS IN. Am J Clin Nutr 80:1710-1716. doi: 10.1093/ajen/80.6.1710S

22. Ritu G, Gupta A, Gupta A (2014) Fortification of foods with vitamin D in India. Nutrients 6:36013623. doi: 10.3390/nu6093601

23. O'Neill CM, Kazantzidis A, Kiely M, et al (2017) A predictive model of serum 25-hydroxyvitamin D in UK white as well as black and Asian minority ethnic population groups for application in food fortification strategy development towards vitamin D deficiency prevention. J Steroid Biochem Mol Biol 173:245-252. doi: 10.1016/j.jsbmb.2016.09.010

24. Madsen K, Rasmussen L, Andersen R, et al (2013) Randomized controlled trial of the effects of vitamin D-fortified milk and bread on serum 25-hydroxyvitamin D concentrations in families in Denmark during winter: the VitmaD study. Am J Clin Nutr 98:374-382. doi: 10.3945/ajcn.113.059469.1

25. Hirvonen T, Sinkko H, Valsta L, et al (2007) Development of a model for optimal food fortification: vitamin D among adults in Finland. Eur J Nutr 46:264-70. doi: 10.1007/s00394-007-0660-0

26. Thuesen B, Husemoen L, Fenger M, et al (2012) Determinants of vitamin D status in a general population of Danish adults. Bone 50:605-610. doi: 10.1016/j.bone.2011.12.016

27. Cashman KD, Ritz C, Kiely M (2017) Improved dietary guidelines for vitamin D: Application of individual participant data (IPD)-level meta-regression analyses. Nutrients 9:1-17.

28. EFSA Panel on Dietetic Products Nutrition and Allergies (NDA) (2012) Scientific Opinion on the Tolerable Upper Intake Level of vitamin D. EFSA J 10:1-45. doi: 10.2903/j.efsa.2012.2813.

29. Burild A, Frandsen HL, Poulsen M, Jakobsen J (2014) Quantification of physiological levels of vitamin D3 and 25-hydroxyvitamin D3 in porcine fat and liver in subgram sample sizes. J Sep Sci 37:2659-63. doi: 10.1002/jssc.201400548

30. National Food Institute DTU (2015) Fooddata. http://frida.fooddata.dk. Accessed 8 Jan 2018

31. Jakobsen J, Wreford Andersen EA, Christensen T, et al (2018) Vitamin D vitamers affect vitamin D status differently in young healthy males. Nutrients $10(1): 12$.

32. National Food Institute DTU (2009) The Danish food composition database (version 7). http://www.foodcomp.dk/v7/. Accessed 4 Mar 2018 
33. Cashman KD, Kiely M, Kinsella M, et al (2013) Evaluation of vitamin D standardization program protocols for standardizing serum 25-hydroxyvitamin D data: A case study of the program's potential for national nutrition and health surveys. Am J Clin Nutr 97:1235-1242. doi: 10.3945/ajen.112.057182

34. Bischof MG, Heinze G, Vierhapper H (2006) Vitamin D status and its relation to age and body mass index. Horm Res 66:211-215. doi: 10.1159/000094932

35. R Core Team (2017) R: A language and environment for statistical computing. R Foundation for Statistical Computing.

36. Tripkovic L, Wilson LR, Hart K, et al (2017) Daily supplementation with $15 \mu \mathrm{g}$ vitamin D 2 compared with vitamin D 3 to increase wintertime 25-hydroxyvitamin D status in healthy South Asian and white European women: a 12-wk randomized, placebo-controlled food-fortification trial. Am J Clin Nutr 106:481-490. doi: 10.3945/ajen.116.138693

37. Ahmad M, Flatzb G (1984) Prevalence of Primary Adult Lactose Malabsorption in Pakistan. Hum Hered 34:69-75. doi: 10.1007/BF00270566

38. Kolars JC, Levitt MD, Aouji M, Savaiano DA (1984) Yogurt - An Autodigesting Source of Lactose. N Engl J Med 5:1-3. doi: 10.1056/NEJM198401053100101

39. Danish National Health Authority (2005) Do you get enough vitamin D? - Important if you have dark skin or wears covered clothing. 0-11.

40. Danish National Health Authority (2009) Make sure that your child's bones are healthy and strong.

41. Pilz S, März W, Cashman KD, et al (2018) Rationale and plan for vitamin D food fortification: A review and guidance paper. Front Endocrinol (Lausanne) 9:1-16. doi: 10.3389/fendo.2018.00373 
Fig. 1

Consort flow diagram of the number of participants enrolled, randomized, completed and analyzed in the ODIN-FOOD study. Consort, Consolidated standards of Reporting Trials. DK: Women of Danish

\section{ODIN FOOD}

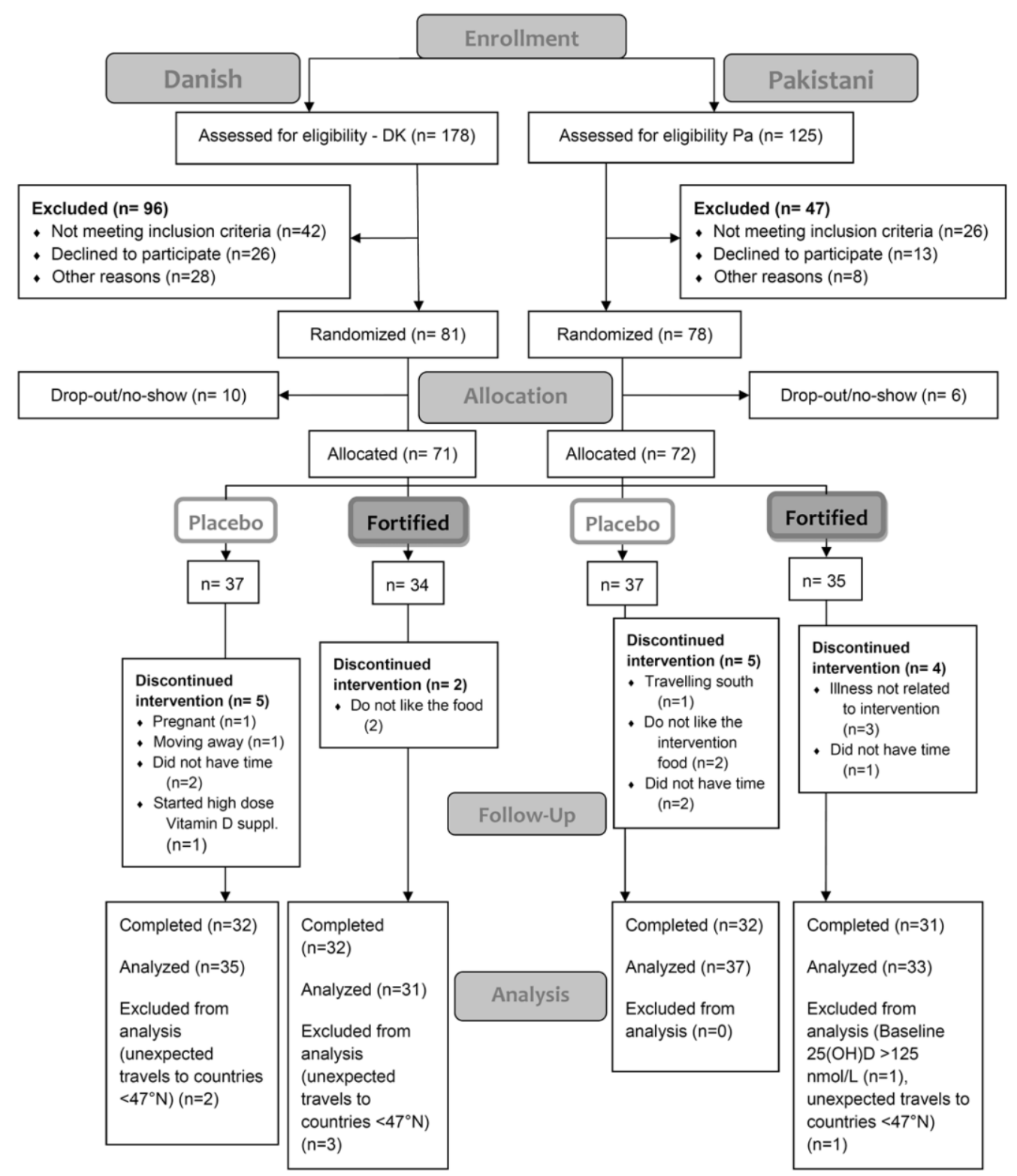


Table 1

531 Nutritional composition, portion size, energy and mean total vitamin D contribution from the fortified and placebo foods

\begin{tabular}{|c|c|c|c|c|c|c|c|c|}
\hline \multirow[t]{2}{*}{$\begin{array}{l}\text { Food } \\
\text { product }\end{array}$} & \multirow[t]{2}{*}{$\begin{array}{l}\text { Macro } \\
\text { nutrients } \\
(\mathrm{g} / 100 \mathrm{~g})^{1}\end{array}$} & \multirow[t]{2}{*}{$\mathrm{Kcal} / 100 \mathrm{~g}^{2}$} & \multirow{2}{*}{$\begin{array}{l}\text { Daily } \\
\text { portion } \\
\text { size } \\
\text { (g/day) }\end{array}$} & \multirow[t]{2}{*}{ Kcal/day } & \multicolumn{2}{|c|}{$\begin{array}{l}\text { Contribution from fortified } \\
\text { product }(\mu \mathrm{g} / \text { day) to: }\end{array}$} & \multicolumn{2}{|c|}{$\begin{array}{l}\text { Contribution from placebo } \\
\text { product }(\mu \mathrm{g} / \text { day }) \text { to: }\end{array}$} \\
\hline & & & & & Vitamin $\mathrm{D}_{3}{ }^{3}$ & $25(\mathrm{OH}) \mathrm{D}_{3}{ }^{4}$ & Vitamin $\mathrm{D}_{3}{ }^{3}$ & $25(\mathrm{OH}) \mathrm{D}_{3}^{4}$ \\
\hline Yoghurt & & 70 & 150 & 105 & $2.00(0.03)^{5}$ & $<0.025$ & $<0.01$ & $<0.025$ \\
\hline Fat & 3.5 & & & & & & & \\
\hline $\mathrm{CHO}$ & 6.6 & & & & & & & \\
\hline Protein & 2.9 & & & & & & & \\
\hline Cheese & & 272 & 60 & 163 & $8.30(0.27)$ & $0.07(0.01)$ & $0.03(0.01)$ & $0.07(0.01)$ \\
\hline Fat & 19 & & & & & & & \\
\hline $\mathrm{CHO}$ & - & & & & & & & \\
\hline Protein & 30 & & & & & & & \\
\hline Eggs & & 141 & 54 & 76 & $0.18(0.17)$ & $0.68(0.43)$ & $0.81(0.06)$ & $0.54(0.04)$ \\
\hline Fat & 9.9 & & & & & & & \\
\hline $\mathrm{CHO}$ & 0.8 & & & & & & & \\
\hline Protein & 12.6 & & & & & & & \\
\hline $\begin{array}{l}\text { Crisp } \\
\text { bread }\end{array}$ & & 460 & 8.9 & 40 & $18.5(2.6)$ & $<0.025$ & $<0.025$ & $<0.025$ \\
\hline Fat & 20 & & & & & & & \\
\hline $\mathrm{CHO}$ & 58 & & & & & & & \\
\hline Protein & 10 & & & & & & & \\
\hline Total & & 943 & - & 384 & $29.0(2.6)$ & $\approx 0.7$ & $\approx 0.8$ & $\approx 0.6$ \\
\hline
\end{tabular}

${ }^{1}$ Macro nutrient composition for the specific products given by the suppliers.

${ }^{2}$ Fortified and placebo foods had similar energy content, only shown once.

${ }^{3}$ Analysed vitamin $\mathrm{D}_{3}$ concentrations of fortified and placebo foods. Contents of vitamin $\mathrm{D}_{2}$ in cheese and eggs in fortified and placebo products would additional account for $<0.03 \mu \mathrm{g} /$ day.

${ }^{4}$ Analysed $25(\mathrm{OH}) \mathrm{D}$ concentration, all $25(\mathrm{OH}) \mathrm{D}_{3}$ values are multiplied with a factor 2.5. Contents of 25 hydroxyvitamin $D_{2}$ in cheese in fortified and placebo products would additional account for $<0.04 \mu \mathrm{g} /$ day. 
Table 2

Baseline characteristics of participants by study group and ethnicity ${ }^{1}$

\begin{tabular}{|c|c|c|c|c|c|c|}
\hline & \multicolumn{3}{|l|}{ Danish } & \multicolumn{3}{|l|}{ Pakistani } \\
\hline & Total $(n=66)$ & Placebo $(n=35)$ & Fortified $(\mathrm{n}=31)$ & Total $(n=70)$ & Placebo $(n=37)$ & Fortified $(n=33)$ \\
\hline Born in Denmark $(\%)$ & 99 & 100 & 99 & 62 & 70 & 54 \\
\hline Mean Age (y) & $33(11)$ & $34(11)$ & $32(11)$ & $36(9)$ & $36(9)$ & $36(10)$ \\
\hline Mean weight in $\mathrm{kg}$ (SD) & $68(13)$ & $70(15)$ & $67(11)$ & $70(12)$ & $68(13)$ & $70(12)$ \\
\hline Mean BMI $\left(\mathrm{kg} / \mathrm{m}^{2}\right)$ & $24(5)$ & $25(5)$ & $24(4)$ & $27(5)^{*}$ & $27(5)$ & $27(5)$ \\
\hline $\begin{array}{l}\text { Mean fat percentage } \\
(\%)\end{array}$ & $31(8)$ & $33(8)$ & $30(7)$ & $37(6) *$ & $37(6)$ & $38(6)$ \\
\hline $\begin{array}{l}\text { Mean serum 25(OH)D } \\
(\mathrm{nmol} / \mathrm{L})\end{array}$ & $49.6(18)$ & $46.2(19)$ & $53.3(17)$ & $46.9(22)$ & $49.0(23)$ & $44.5(21)$ \\
\hline$<9.9 \mathrm{nmol} / \mathrm{L}, \mathrm{n}(\%)$ & $0(0)$ & $0(0)$ & $0(0)$ & $0(0)$ & $0(0)$ & $0(0)$ \\
\hline $\begin{array}{l}\geq 10-<29.9 \mathrm{nmol} / \mathrm{L}, \mathrm{n} \\
(\%)\end{array}$ & $6(9)$ & $5(14)$ & $1(3)$ & $17(24)$ & $8(22)$ & $9(27)$ \\
\hline $\begin{array}{l}\geq 30-<49.9 \mathrm{nmol} / \mathrm{L}, \mathrm{n} \\
(\%)\end{array}$ & $33(50)$ & $20(57)$ & $13(42)$ & $22(32)$ & $11(30)$ & $11(33)$ \\
\hline$\geq 50 \mathrm{nmol} / \mathrm{L}, \mathrm{n}(\%)$ & $27(41)$ & $10(29)$ & $17(55)$ & $31(44)$ & $18(48)$ & $13(40)$ \\
\hline Mean PTH (pmol/L) & $5.0(1.7)$ & $5.3(1.9)$ & $4.9(1.6)$ & $4.4(1.8)^{*}$ & $4.2(1.8)$ & $4.5(1.8)$ \\
\hline $\begin{array}{l}\text { Median vitamin D } \\
\text { intake from the diet } \\
\text { ( } \mu \mathrm{g} / \text { day) }\end{array}$ & $1.5(1.0 ; 2.0)$ & $1.5(1.0 ; 2.0)$ & $1.7(1.0 ; 2.1)$ & $1.1(1.0 ; 2.0)^{*}$ & $1.1(0.8 ; 1.4)$ & $1.0(0.7 ; 1.7)$ \\
\hline $\begin{array}{l}\text { Total median vitamin D } \\
\text { intake from vitamin D } \\
\text { suppl. and multivitamin } \\
\text { suppl. ( } \mu \mathrm{g} / \text { day) }\end{array}$ & $2.9(1.8 ; 9.0)$ & $7.9(4.3 ; 16.0)$ & $2.0(1.0 ; 3.7)$ & $13(6.8 ; 29.3)^{*}$ & $13(7.9 ; 29.3)$ & $13(5.5 ; 22.2)$ \\
\hline $\begin{array}{l}\text { Median dietary calcium } \\
\text { intake ( } \mathrm{mg} / \text { day) }\end{array}$ & $\begin{array}{l}465(324 ; \\
688)\end{array}$ & $487(309 ; 685)$ & $442(331 ; 692)$ & $441(260 ; 589)$ & $422(262 ; 547)$ & $465(259 ; 634)$ \\
\hline $\begin{array}{l}\text { Vitamin D supplements } \\
(\%)\end{array}$ & 15 & 17 & 13 & $61^{\natural}$ & 65 & 58 \\
\hline $\begin{array}{l}\text { Multivitamin } \\
\text { supplements (\%) }\end{array}$ & 24 & 17 & 32 & 30 & 32 & 27 \\
\hline
\end{tabular}


Smokers $(\%)$

Alcohol drinkers $(\%)$

14

Wearing hijab $(\%)$

${ }^{1}$ Means and SD unless otherwise specified. If non-normally distributed, medians and $25^{\text {th }}$

and $75^{\text {th }}$ percentiles. No variables were transformed for analysis.

*Means significantly different from women of Danish origin; Unpaired $t$ test, $P<0.05$

qPercentage significantly different from women of Danish origin; Pearson's chi ${ }^{2}$ test, $P<0.05$ 
Table 3

Total vitamin D intake, and serum 25(OH)D and PTH concentration at baseline and endpoint in each of the four study groups ${ }^{1}$

\begin{tabular}{|c|c|c|c|c|c|}
\hline & \multicolumn{2}{|c|}{ Danish } & \multicolumn{2}{|c|}{ Pakistani } & \multirow[b]{2}{*}{$P^{5}$} \\
\hline & Placebo $(n=35)$ & Fortified $(\mathrm{n}=31)$ & Placebo $(n=37)$ & Fortified $(\mathrm{n}=33)$ & \\
\hline $\begin{array}{l}\text { Total vitamin D } \\
\text { Intake }^{2}, \mu \mathrm{g} / \mathrm{d}\end{array}$ & $1.5(1.0,2.0)^{3 a}$ & $32.0(27.0,34.4)^{\mathrm{b}}$ & $1.1(0.8,1.4)^{\mathrm{a}}$ & $24.2(19.2,30.8)^{\mathrm{c}}$ & $<0.0001$ \\
\hline $\begin{array}{l}\text { Serum } 25(\mathrm{OH}) \mathrm{D}, \mathrm{nmol} / \mathrm{L} \text { : } \\
\text { Baseline } \\
\text { Endpoint } \\
\text { Change }\end{array}$ & $\begin{array}{l}46.2(19)^{4} \\
44.0(17)^{\mathrm{a}} \\
-2.8(9)^{\mathrm{a}}\end{array}$ & $\begin{array}{l}53.3(17) \\
77.8(14)^{\mathrm{b}} \\
26.4(16)^{\mathrm{b}}\end{array}$ & $\begin{array}{l}49.0(23) \\
36.5(16)^{\mathrm{a}} \\
-11.2(12)^{\mathrm{a}}\end{array}$ & $\begin{array}{l}44.5(21) \\
54.7(18)^{\mathrm{c}} \\
10.5(18)^{\mathrm{c}}\end{array}$ & $\begin{array}{l}0.31 \\
<0.0001 \\
<0.0001\end{array}$ \\
\hline $\begin{array}{l}\text { Serum PTH, pmol/L: } \\
\text { Baseline } \\
\text { Endpoint } \\
\text { Change }\end{array}$ & $\begin{array}{l}5.3(1.9) \\
4.7(1.4) \\
-0.54(9.0)\end{array}$ & $\begin{array}{l}4.9(1.6) \\
4.4(1.8) \\
-0.42(16)\end{array}$ & $\begin{array}{l}4.2(1.8) \\
4.3(1.8) \\
-0.002(12)\end{array}$ & $\begin{array}{l}4.5(1.8) \\
4.3(1.5) \\
-0.27(18)\end{array}$ & $\begin{array}{l}0.07 \\
0.97 \\
0.60\end{array}$ \\
\hline
\end{tabular}

${ }^{1} 25(\mathrm{OH}) \mathrm{D}=25$-hydroxyvitamin D; PTH, parathyroid hormone.

${ }^{2}$ Total vitamin D intake during study; placebo groups had only dietary intake, fortified groups had diet plus study fortified foods.

${ }^{3}$ Median $\left(25^{\text {th }}, 75^{\text {th }}\right.$ percentiles $)$.

${ }^{4}$ Means (SD), all such values.

${ }^{5} \mathrm{P}$ values for baseline comparisons by intervention group were determined with the use of a simple one-way ANOVA, followed by a Tukey HSD test.

${ }^{\mathrm{a}, \mathrm{b}, \mathrm{c}}$ Different superscript letters represent significant $(P<0.01)$ differences in group means for endpoint total vitamin $\mathrm{D}$ intake, serum $25(\mathrm{OH}) \mathrm{D}$ and change in serum $25(\mathrm{OH}) \mathrm{D}$. 
Table 4

Number and percentage of women with serum 25(OH)D below 30 and 50 at baseline and endpoint in each of the four study groups

\begin{tabular}{|c|c|c|c|c|}
\hline & \multicolumn{2}{|l|}{ Danish } & \multicolumn{2}{|l|}{ Pakistani } \\
\hline & Placebo & Fortified & Placebo & Fortified \\
\hline $\begin{array}{l}\text { Serum } 25(\mathrm{OH}) \mathrm{D}<30 \\
\text { nmol/L: }\end{array}$ & \multicolumn{2}{|c|}{$\mathrm{n}(\%)$} & \multicolumn{2}{|c|}{$\mathrm{n}(\%)$} \\
\hline Baseline & $5(14)$ & $1(3)$ & $8(22)$ & $9(27)$ \\
\hline Endpoint & $7(23)$ & $0(0)$ & 11(34) & $1(3)$ \\
\hline \multicolumn{5}{|l|}{$\begin{array}{l}\text { Serum } 25(\mathrm{OH}) \mathrm{D}<50 \\
\mathrm{nmol} / \mathrm{L}:\end{array}$} \\
\hline Baseline & $25(71)$ & $14(45)$ & $19(51)$ & $20(60)$ \\
\hline Endpoint & $20(65)$ & $0(0)$ & $25(78)$ & $11(41)$ \\
\hline
\end{tabular}


Table 5

Analysis of covariance models exploring the intervention effects on serum $25(\mathrm{OH}) \mathrm{D}$ response

\begin{tabular}{|c|c|c|c|c|c|c|}
\hline \multirow[b]{2}{*}{ Coefficients } & \multicolumn{3}{|c|}{ Model $1^{1}$ (minimal) } & \multicolumn{3}{|c|}{ Model $2^{2}$ (maximal) } \\
\hline & Effect & $95 \% \mathrm{CI}$ & $P$ & Effect & $95 \% \mathrm{CI}$ & $P$ \\
\hline Intercept ${ }^{3}$ & 16.5 & $(9.76 ; 23.2)$ & $<0.0001(* * *)$ & 33.8 & $(19.6 ; 48.1)$ & $<0.0001(* * *)$ \\
\hline Baseline 25(OH)D & -0.41 & $(-0.52 ;-0.30)$ & $<0.0001(* * *)$ & -0.42 & $(-0.53 ;-0.30)$ & $<0.0001(* * *)$ \\
\hline \multicolumn{7}{|l|}{ Ethnicity: } \\
\hline Danish & - & - & - & - & - & - \\
\hline Pakistani & -8.41 & $(-13.9 ;-2.14)$ & $0.008(* *)$ & -6.12 & $(-12.14 ;-0.07)$ & $0.05(*)$ \\
\hline Danish*Fortified & 31.1 & $(25.0 ; 37.2)$ & $<0.0001(* * *)$ & 33.8 & $(19.6 ; 48.1)$ & $<0.0001(* * *)$ \\
\hline Pakistani*Fortified & 20.3 & $(14.3 ; 26.3)$ & $<0.0001(* * *)$ & 27.7 & $(12.2 ; 43.3)$ & $<0.0001(* * *)$ \\
\hline BMI at baseline & & & & -0.64 & $(-1.16 ;-0.12)$ & $0.02(*)$ \\
\hline Age & & & & -0.05 & $(0.006 ; 0.20)$ & 0.69 \\
\hline
\end{tabular}

${ }^{1}$ Model 1 (minimal): change in vitamin D status Baseline status + intervention group + (ethnicity*intervention group), adjusted $\mathrm{R}^{2}=65 \%$.

${ }^{2}$ Model 2 (maximal): change in vitamin D status $~$ Baseline status + intervention group $+($ ethnicity*intervention group) +

$\mathrm{BMI}+$ Age, adjusted $\mathrm{R}^{2}=67 \%$

${ }^{3}$ The reference group is included in the intercept: Danish ethnicity and placebo study group. 